\title{
PENERAPAN MODEL PROBLEM BASED LEARNING DALAM PENINGKATAN HASIL BELAJAR MATEMATIKA PADA MATERI PELUANG PESERTA DIDIK KELAS XI TATA BOGA 1 SMK NEGERI 1 TARAKAN
}

\author{
Septien Andhika Matsubara ${ }^{1}$ \\ SMK Negeri 1 Tarakan \\ allenaseptin@gmail.com
}

\begin{abstract}
The low results of learning mathematics on the opportunity subject in XI Tata Boga 1 at SMKN 1 Tarakan as the basic of the research. This study aims to improve student learning outcomes using the Problem Based Learning model on the material opportunities in Class XI Tata Boga 1 at SMKN1 Tarakan. This research is a classroom action research conducted in 2 cycles, where the cycle stages consist of 1) planning, 2) implementation, 3) observation, 4) reflection. Data collection techniques using tests and observations. The instrument used in the form of a final test of learning to determine the increase in learning outcomes and teacher and student observation sheets to determine activities during the learning process. Data analysis used the average value and classical learning completeness. The results showed that (1) the learning outcomes of the first cycle of meeting 1 were $40.65 \%$, meeting 2 was $46.9 \%$ and meeting 3 there was $53.12 \%$ who achieved learning completeness, in cycle II students' learning completeness at meeting 1 reached $62.5 \%$, meeting 2 was $75 \%$ and meeting 3 there was $87.5 \%$ who achieved mastery learning.It can be concluded that the problembased learning model can improve mathematics learning outcomes on the opportunity material for class XI Tata Boga I SMKN I Tarakan.
\end{abstract}

Keywords: Problem Based Learning, Improving of the Study Result, Oppotunity Subject.

\begin{abstract}
Abstrak
Rendahnya hasil belajar matematika pada materi peluangdi Kelas XI Tata Boga 1 SMKN 1 Tarakan menjadi dasar penelitian ini. Penelitian ini bertujuan untuk meningkatkan hasil belajar peserta didik menggunakan model Problem Based Learning pada materi Peluang di Kelas XI Tata Boga 1 SMKN 1 Tarakan. Penelitian ini merupakan penelitian Tindakan Kelas yang dilaksanakan dalam 2 siklus, dimana tahapan siklus terdiri dari 1) Perencanaan, 2) pelaksanaan,3) pengamatan, 4) refleksi. Teknik pengumpulan data dengan menggunakan tes dan observasi. Instrumen yang digunakan berupa tes akhir pembelajaran untuk mengetahui peningkatan hasil belajar dan lembar observasi guru dan peserta didik untuk mengetahui aktivitas selama proses pembelajaran. Analisis data menggunakan nilai rata-rata dan ketuntasan belajar klasikal.Hasil penelitian menunjukkan bahwa (1) hasil belajar siklus I pertemuan 1 terdapat 40,65\%, pertemuan 2 terdapat 46,9\% dan pertemuan 3 terdapat $53,12 \%$ yang mencapai ketuntasan belajar, pada siklus II ketuntasan belajar peserta didik pada pertemuan 1 mencapai $62,5 \%$, pertemuan 2 terdapat $75 \%$ dan pertemuan 3 terdapat 87,5\% yang mencapai ketuntasan belajar.Dengan demikian dapat disimpulkan bahwa model problem based learning dapat meningkatkan hasil belajarmatematika pada materi peluang siswa kelas XI Tata Boga 1 SMKN 1 Tarakan
\end{abstract}

Kata kunci: Problem Based Learning,Peningkatan Hasil Belajar, Materi Peluang

Cara Menulis Sitasi: Matsubara, S., A (2020). Penerapan Model Problem Based Learning dalam Peningkatan Hasil Belajar Matematika pada Materi Peluang Peserta Didik Kelas XI Tata Boga 1 SMK Negeri 1 Tarakan. Mathematic Education and Aplication Journal,2(2), 37-41.

Materi Peluang merupakan materi yang penting karena materi peluang memberikan peserta didik dasar dalam menaksir kejadian-kejadian yang mungkin akan terjadi dalam kehidupan nyata. Peserta didik akan dikatakan tuntas dalam proses pembelajaran jika telah mencapai kriteria ketuntasan 
minimal.Pada kenyataanya selama beberapa semester untuk materi Peluang masih banyak peserta didik yang nilainya belum mencapai kriteria ketuntasan minimal.Berdasarkan hasil observasi guru selama KBM berlangsung, partisipasi peserta didik dalam pembelajaran materi peluang cenderung rendah. Hal ini terlihat dengan kurang aktifnya peserta didik dalam bertanya terutama mengenai halhal yang tidak mereka pahami, dan jika diberi pertanyaan peserta didik lebih banyak diam. Peserta didik juga tidak mampu menyelesaikan soal-soal yang diberikan oleh guru dan sering mencontek jawaban teman dibandingkan mencari sendiri cara atau gagasan untuk menjawab soal-soal tersebut. Usaha yang dilakukan yaitu guru dapat menggunakan model yang mengarah pada kemampuan pemecahan masalah, terutama pada materi peluang dimana peserta didik dituntut untuk dapat mencari solusi dari masalah-masalah nyata dalam kehidupan sehari-hari. Salah satu model pembelajaran yang dapat digunakan adalah Model Problem Based Learning atau pembelajaran berbasis masalah. Menurut Glazer (dalam Rusmono,2012:24) "Problem based learning merupakan suatu strategi pengajaran dimana peserta didik aktif dihadapkan pada masalah kompleks dalam situasi yang nyata". Problem based learning merupakan suatu pembelajaran inovatif yang dapat memberikan kondisi belajar aktif kepada peserta didik, melibatkan peserta didik untuk dapat memecahkan suatu masalah melalui tahap-tahap metode ilmiah sehingga peserta didik dapat mempelajari pengetahuan yang berhubungan dengan masalah tersebut dan sekaligus memiliki keterampilan untuk memecahkan masalah. Pelaksanaan model Problem Based Learning terdiri atas lima tahap proses yaitu: ( Ibrahim dalam Trianto:2009:98)

a. Tahap Pertama adalah proses orientasi peserta didikpada masalah. Pada tahap ini guru menjelaskan tujuan pembelajaran, menjelaskan logistik yang diperlukan, memotivasi peserta didikuntuk terlibat dalam aktivitas pemecahan masalah dan mengajukan masalah.

b. Tahap kedua, mengorganisasikan siswa. Pada tahap ini guru membagi peserta didikkedalam kelompok, membantu peserta didikmendefinisikan dan mengorganisasikan tugas belajar yang berhubungan dengan masalah.

c. Tahap ketiga, membimbing penyelidikan individu atau kelompok. Pada tahap ini guru mendorong peserta didikuntuk mampu memecahkan permasalahan.

d. Tahap keempat, mengembangkan dan menyajikan hasil. Pada tahap ini guru membantu peserta didikdalam merencanakan dan menyiapkan laporan sesama temannya.

e. Tahap kelima, menganalisis dan mengevaluasi proses dan hasil pemecahan masalah. Pada tahap ini guru melakukan refleksi atau mengevaluasi hasil belajar siswa.

Uno(2007:213), menyatakan bahwa hasil belajar adalah perubahan tingkah laku yang relatif menetap dalam diri seseorang sebagai akibat dari interaksi seseorang dengan lingkungan. Hasil belajar memiliki beberapa ranah atau kategori dan secara umum merujuk kepada aspek pengetahuan, sikap dan keterampilan.Hamalik dalam jihad dan Haris (2012:15), juga berpendapat bahwa hasil belajar adalah segala sesuatu yang menjadi milik peserta didiksebagai akibat dari kegiatan belajar yang 
dilakukan. Bloom dalam Jihad dan Harris (2012: 14), ada tiga ranah (domain) hasil belajar yaitu kognitif, afektif dan psikomotorik. Dari pernyataan tersebut dapat disimpulkan bahwa hasil belajar adalah perubahan tingkah laku peserta didiksetelah melakukan proses belajar mengajar yang sesuai dengan tujuan pengajaran yang meliputi kognitif, afektif dan psikomotorik.

Salah satu penelitian yang telah dilakukan dalam peningkatan hasil belajar peserta didik dengan menggunakan model problem based learning pada materi peluang yaitu Katiasri (2014) yang berfokus pada tingkat SMP. Berdasarkan penelitian yang telah dilakukan maka dalam penelitian ini dilaksanakan untuk kelas XI tingkat SMK. Maka tujuan dari penelitian ini adalah untuk meneliti bahwa hasil belajar matematika peserta didik kelas XI Tata Boga 1 SMKN 1 Tarakan pada materi peluang dapat ditingkatkan dengan model Problem Based Learning".

\section{METODE}

Jenis penelitian yang digunakan dalam penelitian ini adalah Penelitian Tindakan Kelas. Arikunto(2012:3) menyatakan bahwa penelitian tindakan kelas merupakan suatu pencermatan terhadap kegiatan belajar berupa sebuah tindakan, yang sengaja dimunculkan dan terjadi dalam kelas secara bersama. Penelitian dilakukan dengan dua tahapan siklus. Dimana setiap siklus meliputi (1) Perencanaan, (2) Pelaksanaan, (3) Pengamatan dan (4) Refleksi.

Subjek penelitian ini adalah peserta didik kelas XI tata Boga 1 SMKN1 Tarakan.Peserta didik tersebut berjumlah 32 peserta didik yang terdiri dari 11 peserta didik laki-laki dan 21 peserta didik perempuan. Sementara objek dari penelitian ini adalah meningkatkan hasil belajar dengan menggunakan model pembelajaran Problem Based Learning pada materi Peluang kelas XI Tata Boga 1 SMK Negeri 1 Tarakan

Instrumen yang digunakan dalam pengumpulan data ini yaitu menggunakan tes akhir pembelajaran, lembar observasi peserta didik dan lembar observasi guru. Teknik pengumpulan data dalam penelitian ini adalah dengan menggunakan tes dan obsevasi.Sukardi (2008:139) mengatakan bahwa tes prestasi pada umumnya mengukur penguasaan dan kemampuan para peserta didik setelah mereka selama kurun waktu tertentu menerima proses belajar mengajar dari guru.

Ketuntasan individu dihitung dengan menggunakan analisis deskriptif prosentase yaitu:

$$
\text { Presentase }(\%)=\frac{\text { jumla } h \text { skor yang diperole } h}{\text { jumla } h \text { skor maksi mal }} \times 100 \%
$$

Ketuntasan belajar klasikal dihitung dengan menggunakan analisis deskriptif prosentase yaitu:

$$
\text { Prosentase }(\%)=\frac{\text { jumla } h \text { siswa yang tuntas belajar }}{\text { jumla } h \text { seluru } h \text { siswa }} \times 100 \%
$$




\section{HASIL DAN PEMBAHASAN}

Penelitian yang dilakukan memperoleh hasil berupa nilai dari tes akhir pembelajaran. Peningkatan hasil belajar peserta didik selama pelaksanaan tindakan kelas dapat dilihat pada tabel 1 berikut.

Tabel 1. Peningkatan Hasil Belajar Peserta Didik

\begin{tabular}{|l|l|c|c|c|}
\hline No & Kegiatan & Banyaknya & Persentase (\%) & Rata-rata Nilai \\
\hline 1 & Pertemuan 1 & 13 & 40,65 & 57,94 \\
\hline 2 & Pertemuan 2 & 15 & 46,9 & 70,31 \\
\hline 3 & Pertemuan 3 & 17 & 53,12 & 70,72 \\
\hline 4 & Pertemuan 4 & 20 & 62,5 & 71,88 \\
\hline 5 & Pertemuan 5 & 24 & 75 & 79 \\
\hline 6 & Pertemuan 6 & 28 & 87,5 & 80,25 \\
\hline
\end{tabular}

Sedangkan grafik peningkatan hasil belajar peserta didik dapat dilihat pada grafik berikut.

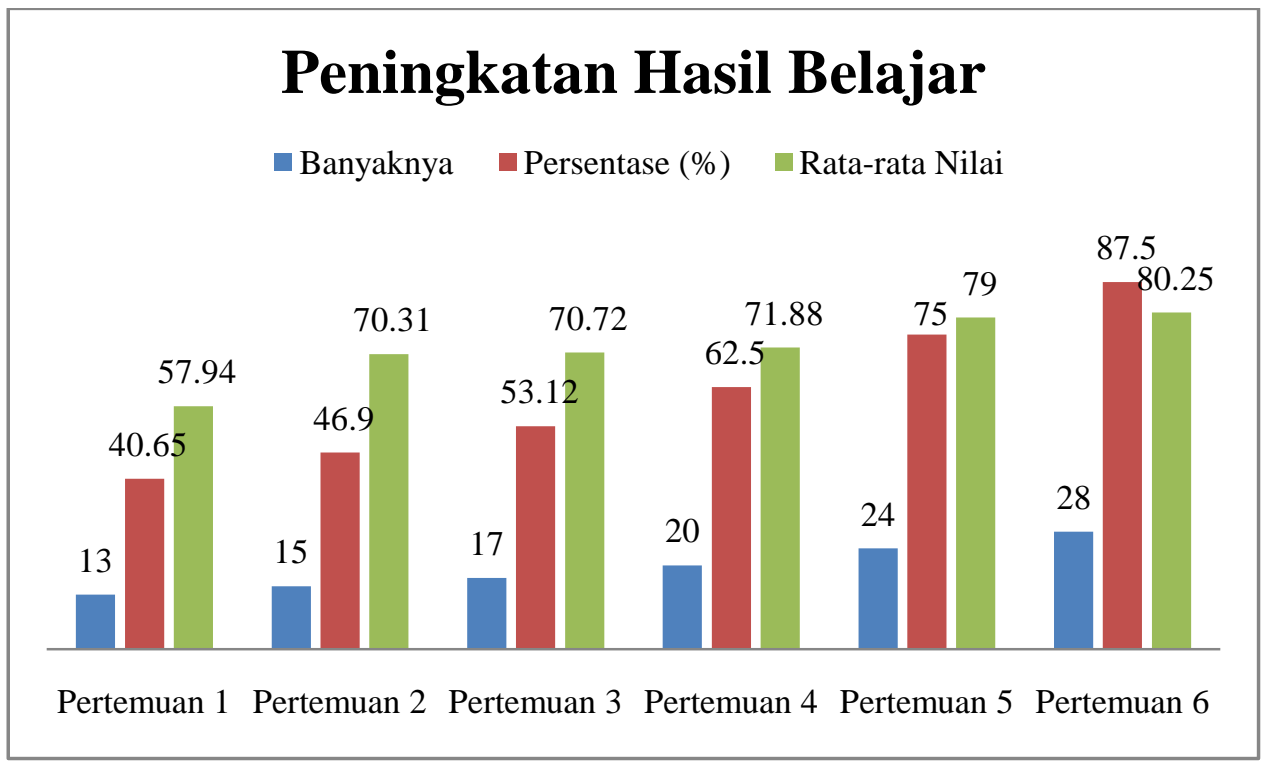

Gambar 1. Peningkatan Hasil belajar

Dari data yang telah diapaparkan di atas hasil penelitian menunjukkan bahwa model pembelajaran problem based learning dapat meningkatkan hasil belajar peserta didik. Hal ini dapat dilihat dari semakin baiknya pemahaman peserta didik terhadap materi matematika yang disampaikan guru, yakni ketuntasan belajar meningkat dari siklus I hingga siklus II yaitu masing-masing ketuntasan pada siklus I pertemuan pertama hanya 13 orang peserta didik atau 40,65\% saja yang tuntas, dan pada siklus II pertemuan keenam meningkat menjadi 28 orang peserta didik atau 87,5\% tuntas secara klasikal serta nilai rata-rata peserta didikpun meningkat pada siklus I pertemuan pertama 57,94 meningkat pada siklus II pertemuan keenam menjadi 80,25. Sehingga melampaui kriteria ketuntasan minimal (KKM) yang diterapkan sekolah, yakni 72 walaupun masih ada 4 orang peserta didik atau $12,5 \%$ belum mencapai ketuntasan minimal maka akan diberikan tugas remidial dalam pertemuan tersendiri sehingga mampu mencapai ketuntasan dalam belajar. 


\section{KESIMPULAN}

Setelah diterapkan dengan tahapan yang telah direncanakan, maka penelitian dengan model problem based learning dapat meningkatkan hasil belajarmatematika pada materi peluang siswa kelas XI Tata Boga 1 SMKN 1 Tarakan. Hasil penelitian menunjukkan bahwa hasil belajar siswa pada siklus I adalah 40,65\% dari peserta didik yang tuntas. Sedangkan pada siklus II sebanyak $87,5 \%$ peserta didik yang tuntas. Dengan memperhatikan hasil penelitian dengan ketuntasan 87,5\% dengan rata-rata nilai 80,25 maka penelitian dihentikan walaupun masih terdapat 4 peserta didik atau 12,5\% yang belum tuntas amak akan diberikan remidial tersendiri dalam waktu yang berbeda sehingga semua peserta didik tuntas dalam pembelajaran. Adapun saran untuk penelitian ini adalah agar guru dapat membuat desain pembelajaran menggunakan model problem based learning yang sesuai dengan materi tertentu. Semoga penelitian ini dapat bermanfaat dan menjadi sumber rujukan ataupun referensi penelitian selanjutnya.

\section{DAFTAR PUSTAKA}

Arikunto, S. (2011). Prosedur Penelitian: Suatu Pendekatan Praktik. Edisi. Revisi VII. Jakarta: PT. Rineka Cipta.

Jihad., Asep., \& Haris, A. (2012). Pembelajaran Kontekstual: Konsep dan Aplikasi. Bandung : PT. Refika Aditama.

Katiasri. (2014). Pembelajaran Berdasarkan Masalah (Problem-Based Learning) Pada Materi Peluang Kejadian Sederhana Di Kelas IX SMP Negeri 3 Tulungagung. (Penelitian Tindakan Kelas)

Rusman. (2012). Model - Model Pembelajaran. Depok: PT Rajagrafindo Persada.

Trianto. (2007). Mendesain Model Pembelajaran Inovatif-Progresif. Jakarta: Kencana

Uno, H. B. (2007). Model Pembelajaran: Menciptakan Proses Belajar Mengajar Yang Kreatif dan Efektif. Jakarta : PT Bumi Aksara. 